\title{
SUS304Lステンレス鋼焼結体の諸特性に及ぼす $\mathrm{S}, \mathrm{Cu} よ ひ ゙ \mathrm{Sn}$ 添加の影響
}

加藤哲男*, 草加勝司*, 久田建男**

\section{Influence of $\mathrm{S}, \mathrm{Cu}$ and $\mathrm{Sn}$-Additions on the Properties of SUS304L Stainless Steel Powders}

Tetsuo Katoh, Katsushi Kusaka and Tatsuo Hisada

\section{Synopsis}

An investigation was made on the characteristics of SUS304L bearing $\mathrm{Cu}$ and $\mathrm{Sn}$ and 303 stainless steel powders produced by water-atomization and, machinability, mechanical properties and corrosion resistance of sinterd materials made of these powders, have also been studied.

The results obtained are as follows:

(1) SUS303 stainless steel powder has a poor compressibility due to the hard CrS precipitate in matrix.

(2) The compressibility of SUS303 can be improved to the level of SUS304L stainless steel powderds by $\mathrm{Cu}$-addition of about $4 \%$.

(3) The machinability of $\mathrm{Cu}$-added 303 type sintered steel is improved by $\mathrm{Sn}$-addition of about $1 \%$ consequently, tool life is prolonged in the increasing order as $304 \mathrm{~L}(\mathrm{Sn}) \rightarrow 303 \rightarrow 304 \mathrm{~L}-\mathrm{Cu} \cdot \mathrm{Sn} \rightarrow 303-\mathrm{Cu} \cdot \mathrm{Sn}$.

(4) $\mathrm{Cu}$ and $\mathrm{Sn}$ additions to 303 type sintered steel lower the ductibity by about $20 \%$, while it practically suppresses the surface rusting of sintered steel which is caused by sulfer addition in $5 \%$ salt spray corrosion test.

\section{1. 緒 $\overline{\bar{E}}$ \\ 粉末治金はブレス焼結工程のみで同一形状の焼 結部品を量産できることを特徴とし，本来奶削加}

\footnotetext{
昭和58年 7 月 18 日 受付

十日本鉄鋼協会第100回講演大会（九州）で発表

大同特殊䤾和中央研究所，工博

**大同特殊鋼中央研究所
}

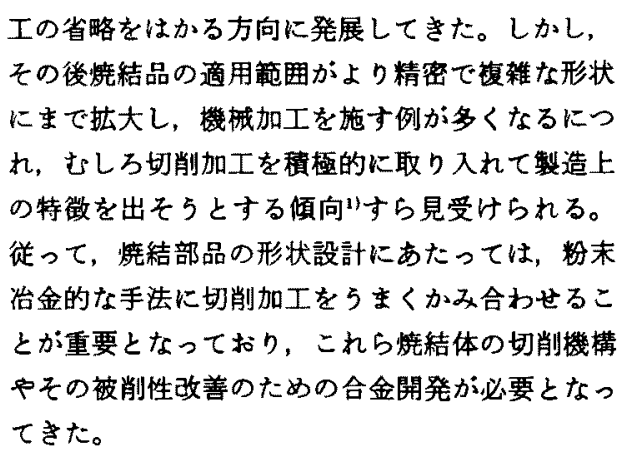


これまで䅉結鉄の被削性に関しては2，3の研 究)ークが行われてはいるすのの, ステンレス鋼焼 結体については簡単な切削試験例が報告明されて いるにすぎず，その被削性改善に対する方策は得 られていないのが現状である。本来ステンレス鋼 は材啠的に鞓延性が高いため切削などの機诚加工 がしにくいが，その焼結品は内部気孔を有するた め浴製材に比べ被削性の様相が異なることが予想 される。

そこで著者らは，各種ステンレス鋼烓結体の被 削性について詳細な研究9),10)を行い，溶製材とは 異なった幾つかの新しい知見を得ることができ た。その中で溶製材と同様，ステンレス鋼焼結体 においてすSの添加に上る被削性改善奻果を見い 出したが，反面 Sは粉末特性，特にブレス特性を 劣化させ，㜔結体の耐食性にも悪影響を及ぼすこ とが判明した。そこで先にブレス特性の改善効果 を確認" ”した $\mathrm{Cu}$ 添加の外，耐食性改善に有奻な $\mathrm{Sn}^{122}$ k注目し，办喷霛 $304 \mathrm{~L}$ 粉末に対するSおよ び $\mathrm{Cu}, \mathrm{Sn}$ 複合添加の影錯について検討すること とした。

\section{2. 供試材およひ実験方法}

水噴篛法に上る SUS304L ( $19 \mathrm{Cr}-10.5 \mathrm{Ni}-\mathrm{Fe})$ 粉 末を基本組成とし，これに $\mathrm{S} ， \mathrm{Cu}$ および $\mathrm{Sn}$ 適 宜添加した合金粉末を10種類製造した。この際， $\mathrm{C}, \mathrm{Si}$ および Mn 量は粉末治金用のステンレス鋼
粉末に適した範囲 ${ }^{13}$ に調整した。いずれの粉末 むー100meshに分級し試験に供した。その化学成 分を Table 1 に示す。

プレス特性としてはJSPM 標準1ー64に準じた

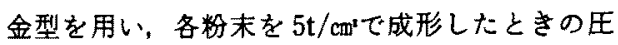
㸮密度を測定した。この際潤滑剂としてステフリ

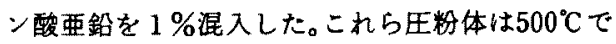
脱ろ5後, $1200^{\circ} \mathrm{C} て ゙ 1 \mathrm{hr}, 10^{-3}$ Torr の真空中で焼 結し，密度を測定し紟密化保数を求めた。

一方，結体の性質としては，各粉末を 5 ～8t/ $\mathrm{cm}^{2}$ で成形し， $1200^{\circ} \mathrm{C} て ゙$ 真空焼結して得られた試 片について引張試験および切削試験を行った。試 駼片形状は前者はJSPM 標準に準拠し，後者は $\phi 38 \times 35 \mathrm{~mm}$ とした。

焼結体の被削性についてはTable 2 に示す条 件でドリル切削試験を行い，切削抵抗および工具 寿命を求めた。これら切削試験中に発生した切首 の色調および形状を観察した。加工後のトリル穴 について表面肌を観察した。また，5\%塩水噴籍 試鈋を行い試片の発錆状況を調へ，特に $\mathrm{Cu}, \mathrm{Sn}$ 䙉 合添加材に生成する折出物の化学組成については X線マイクロアナライザーにより調查した。

\section{3. 実験結果书よU゙考察}

Fig. 1 およびFig. 2 は各粉末を $5 \mathrm{t} / \mathrm{cm}^{2} て ゙$ 成形 した圧粷体の密度とそれを $1200^{\circ} \mathrm{C} て ゙ 1 \mathrm{hr}$ 真空䁳 結したときの密度变化を示したものである。Fig.1

Table 1. Chemical composition.

(wt \%)

\begin{tabular}{|c|c|c|c|c|c|c|c|c|c|}
\hline No. & $\mathrm{C}$ & $\mathrm{Si}$ & $\mathrm{Mn}$ & S & $\mathrm{Cu}$ & $\mathrm{Ni}$ & $\mathrm{Cr}$ & $\mathrm{Sn}$ & Note \\
\hline 1 & 0.018 & 0.87 & 0.09 & 0.010 & 0.02 & 10.53 & 18.88 & - & $\begin{array}{c}\text { SUS } \\
304 \mathrm{~L} \\
\end{array}$ \\
\hline 2 & 0.016 & 0.93 & 0.21 & 0.010 & 4.05 & 10.52 & 18.96 & - & \multirow{6}{*}{$\begin{array}{l}\text { SUS } \\
304 \mathrm{~L} \\
\text { type }\end{array}$} \\
\hline 3 & 0.027 & 1.00 & 0.26 & 0.017 & 0.02 & 10.39 & 18.76 & 0.73 & \\
\hline 4 & 0.024 & 0.84 & 0.14 & 0.011 & 3.97 & 10.67 & 19.56 & 0.27 & \\
\hline 5 & 0.027 & 0.87 & 0.15 & 0.010 & 3.92 & 10.64 & 19.82 & 0.69 & \\
\hline 6 & 0.027 & 0.84 & 0.15 & 0.006 & 3.83 & 10.37 & 18.72 & 1.10 & \\
\hline 7 & 0.024 & 0.92 & 0.15 & 0.005 & 4.06 & 10.37 & 18.87 & 2.17 & \\
\hline 8 & 0.023 & 0.87 & 0.08 & 0.207 & 0.01 & 10.52 & 18.75 & - & $\begin{array}{c}\text { SUS } \\
\quad 303 \\
\end{array}$ \\
\hline 9 & 0.018 & 0.85 & 0.07 & 0.204 & 4.00 & 10.44 & 19.00 & - & \multirow{2}{*}{$\begin{array}{l}\text { SUS } \\
303 \\
\text { type }\end{array}$} \\
\hline 10 & 0.023 & 0.77 & 0.13 & 0.208 & 3.82 & 10.61 & 19.65 & 0.72 & \\
\hline
\end{tabular}


Table 2. Cutting conditions for drilling.

\begin{tabular}{l|c|c}
\hline & Cutting force & Tool life \\
\hline Tool & $\begin{array}{l}\text { SKH9 } \phi 10 \\
\text { Point angle } 118^{\circ}\end{array}$ & $\begin{array}{l}\text { SKH9 } \phi 5 \\
\text { Point angle } 118^{\circ}\end{array}$ \\
\hline Feed rate & $0.10 \mathrm{~mm} / \mathrm{rev}$. & 0.07 \\
\hline Depth of hole & $13 \mathrm{~mm}$ & 15 \\
\hline Max. Cutting speed & $10 \mathrm{~m} / \mathrm{min}$ & $9 \sim 55$ \\
\hline
\end{tabular}

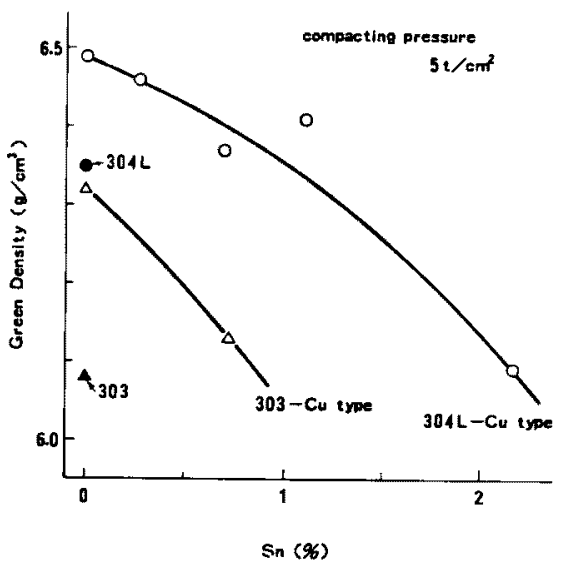

Fig. 1. Green density vs. chemical composition.

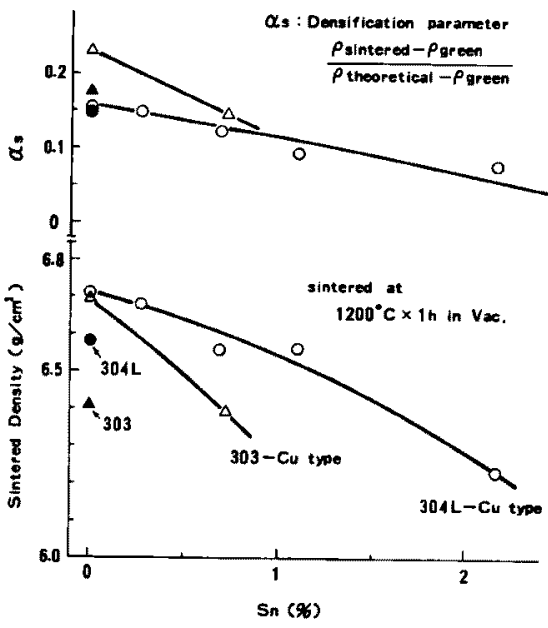

Fig. 2. Sintered density, $\alpha_{\mathrm{s}}$ vs. chemical composition.
でSnを添加しないと $304 \mathrm{~L} に$ 比べ Sを0.2\%含有

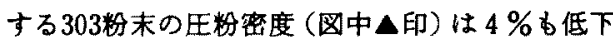
している。これは噴䉘時の急冷効果によって粉末 中に細析出したSが CrSを主体とする硬い硫 化物となり，ブレス成形時，粒子本来のるつ可塑 性を減ずるためと考えられる。

これにCuを $4 \%$ 添加（ $\triangle$ 印）すると，もとの 304L 粉末の特性近くにまで压綟性が回復する。こ の間の状況を 304L および303両系の粉末で比較 すると，後者の方が Cuによる王維性の改善効果 が大きいことがわかる。さらに，この303-Cu粉末 に Sn を複合添加すると王縮性は再び低下し，Sn $1 \%$ 添加ですとの303粉末とは驻同程度の王縮性 を示すようになる。これも浴湯噴霧の結果，原子 半径の大きいSnが粉末中に㤝制固溶され，一部 析出することにより硬化したものと判断される。

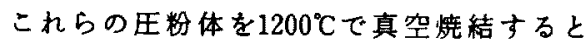
$304 \mathrm{~L}$ 拈よび303両系とも密度は $0.2 \sim 0.3 \mathrm{~g} / \mathrm{cm}^{3}$ の 範囲で增加し，特に No. 9 の 303Cu 粉末の䧺密化 俰数 $\alpha_{\mathrm{s}}{ }^{15)}$ (図中表示) の大きいことが注目される が,これはー350meshの細粉が $62 \%$ む涺入するた め烸結が促進されたものと考えられる。また両系 のCu含有粉に Sn を添加するにつれて $\alpha_{5}$ は若干 ながら減少し，本実験の場合 $\mathrm{Ni}_{3} \mathrm{Sn}_{2}, \mathrm{Sn} \cdot \mathrm{NiFe}$ $\left(\boldsymbol{\alpha}^{\prime}\right)$ の粒界析出に上る焼結促進効果 ${ }^{(6)}$ は認めら れなかった。

Fig. 3 は密度を $6.5 \mathrm{~g} / \mathrm{cm}^{3}$ の一定とした焼結試 片についてドリル切削試験を行い，切削抵抗に対 する $\mathrm{Cu}, \mathrm{Sn}$ 複合添加の影響を調べたものである。 No.1の 304LにSnだけを添加（図中×印）する より Cu と複合添加した焼結体の方が切削抵抗が 小さい。ただしこの場合，Snを1\%以上增量し ても抵抗はあまり变化しない。同様に，No.9の $303 \cdot \mathrm{Cu}$ 粉末に $\mathrm{Sn} 0.7 \%$ 添加した砕結体ではると 
の S 添加効果に相乗された形で切削抵抗が减少す ることがわかる。Photo. 1 にこれら切削試験後の 試片のドリル穴と切屑についての観察例を示す。 304L と比へ，いずれの場合も切くずは覀くかつ細 かく破挽され，ドリル穴（底面）は此較的平滑で ある。

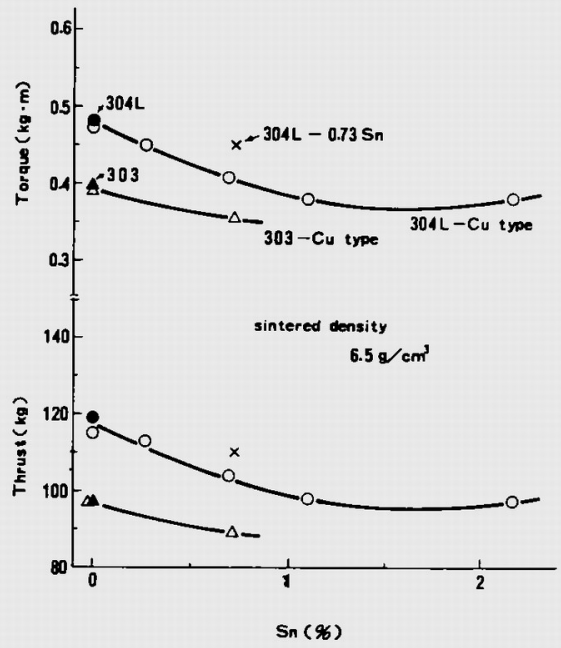

Fig. 3. Cutting force vs. chemical composition.
これらの試験結果はFig.4の焼結体の工具寿 命にも反映され，切削抵抗を密度 $6.8 \mathrm{~g} / \mathrm{cm}^{3}$ 近くの

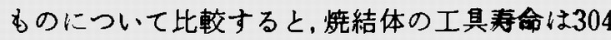
$\mathrm{L} \rightarrow 304 \mathrm{~L}-\mathrm{Sn} \rightarrow 303 \rightarrow 304 \mathrm{~L}-\mathrm{Cu} \cdot \mathrm{Sn} \rightarrow 303-\mathrm{Cu}$ • $\mathrm{Sn}$ の順に改善されることがわかる。

Fig. 5 はFig. 4 に示す工具寿俞加 $300 \mathrm{~mm}$ に達 する切削速度と対応する切削トルクとの関係を示

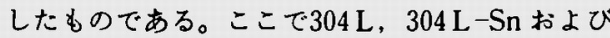
303系の材料の切削速度と切削抵抗は匡同一直 線で表されるのに対し， $\mathrm{Cu}, \mathrm{Sn}$ を複合添加した試 料は別の直線で表されより優れた被削性を有する ことがわかる。Fig. 3 と Fig. 4 を対比すると S 采 と $\mathrm{Cu}-\mathrm{Sn}$ 系とでは切削機構への作用が異なるこ とがわかるすなわち $\mathrm{S}$ 単独では焼結体の切削抵 抗の低減作用の方が大きいのに対し， $\mathrm{Cu}, \mathrm{Sn}$ の複 合添加は工具寿命を延長することに寄与している ものと見られる。

Photo. 2 にこれら切削試験材の断面, ミク口組 織の観察例を示す。303焼結体には前述の CrSに 相当する析出物が点在している。また二つの Cu・ $\mathrm{Sn}$ 複合添加材には粒界に灰色またはやや赤味が かかった析出物が現われ，X線マイクロフナライ ザーでの線分析結果からはFig. 6 に示すよ $5 に$ $\mathrm{Cu}$ と $\mathrm{Sn}$ が共存し，その領域で Ni が濃化してい

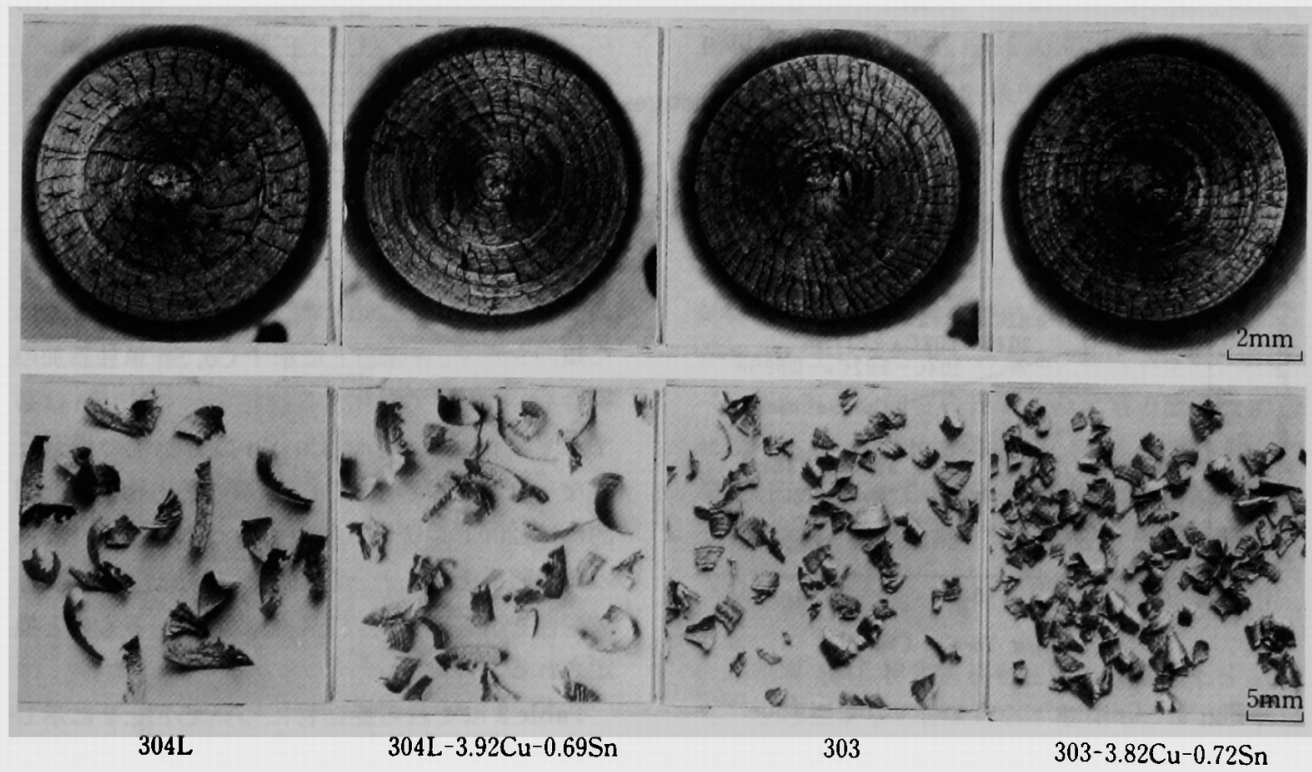

Photo. 1. Drilled hole and cutting chip. 


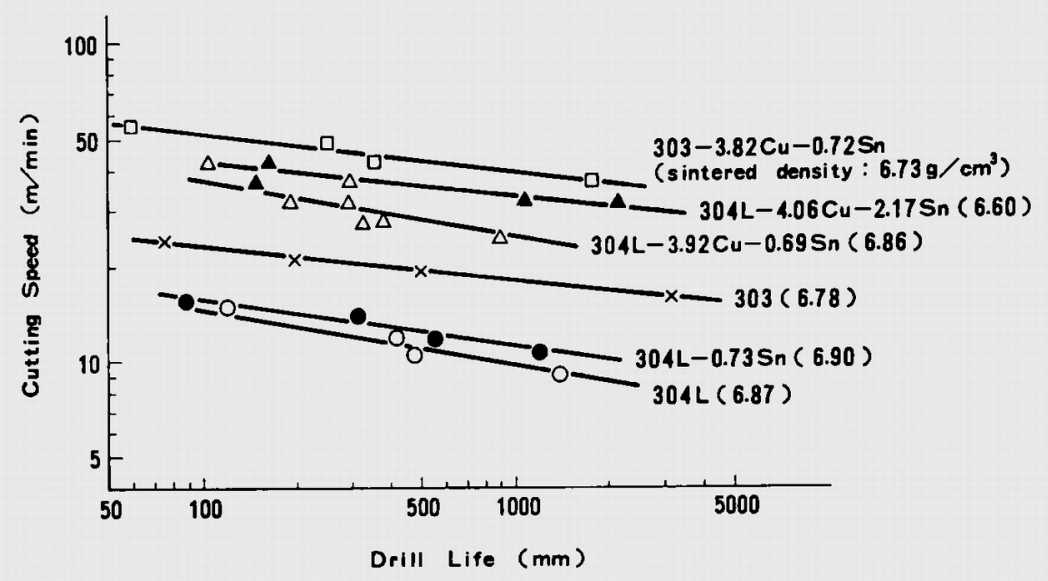

Fig. 4. Cutting speed vs. drill life.

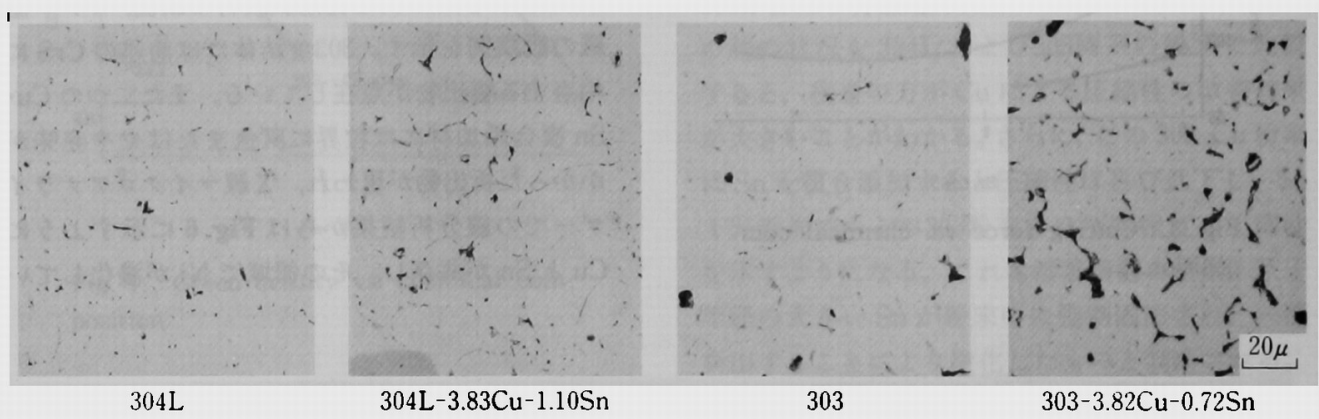

Photo. 2. Micro-structures of sintered compacts.

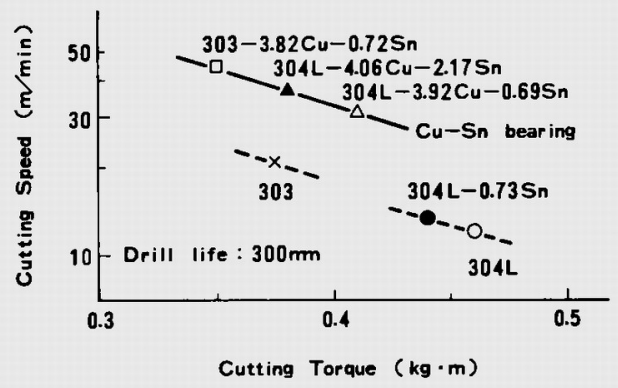

Fig. 5. Cutting speed vs. cutting torque.
ることが確認された。この $\mathrm{Cu}, \mathrm{Sn}$ 共存形態は Fig. 7 のオーシェ電子分光分析のチャートからむ 裏づけられ，Cu と $\mathrm{Sn}$ の深さ方向の分布はよくに た傾向を示す。各図右上に示す $\mathrm{Cu}, \mathrm{Sn}$ 単独添加の 場合 $\mathrm{Cu}$ は表層で濃化する傾向を示すが, Sn は必 ずしも濃化して扣らずCu-Sn 複合添化の場合と 異なった傾向を示す。Cu-Sn 系の析出物は状態図 的には $1200^{\circ} \mathrm{C}$ 以下に低融点をもつ $\mathrm{Ni}(\mathrm{Cu}) \mathrm{Sn}$ 系 の共晶組成之見られ，焼結体を切削加工する場合， 被削性を改善する要因として偟いているすのと推 定される。

Table 3 にこれら焼結材について Fig. 2 に示し 密度における引張特性を示した。焼結体中に Sを 添加した場合の引張強さや降伏点の变化は小さい 


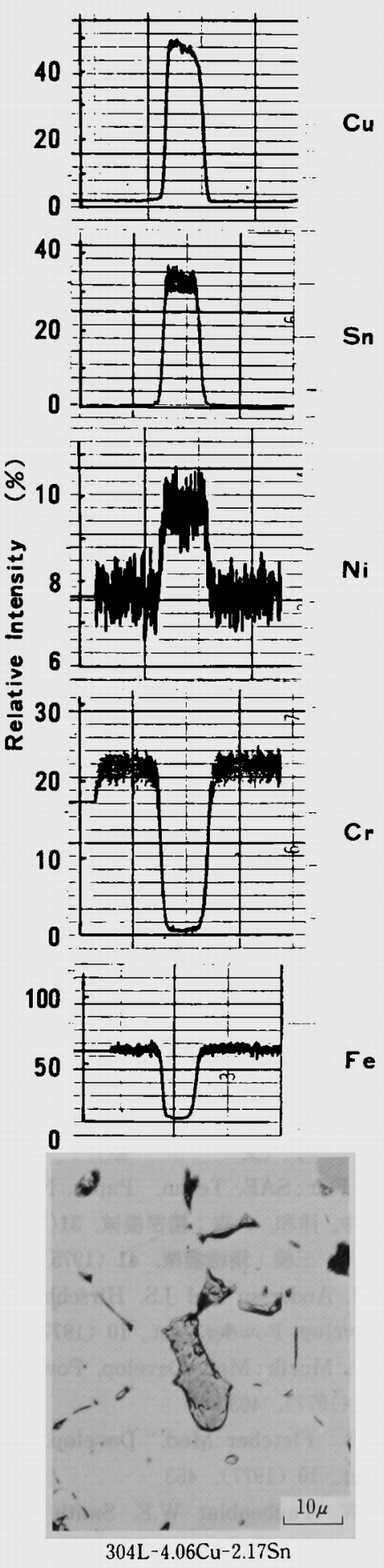

Fig. 6. EPMA line-analysis.

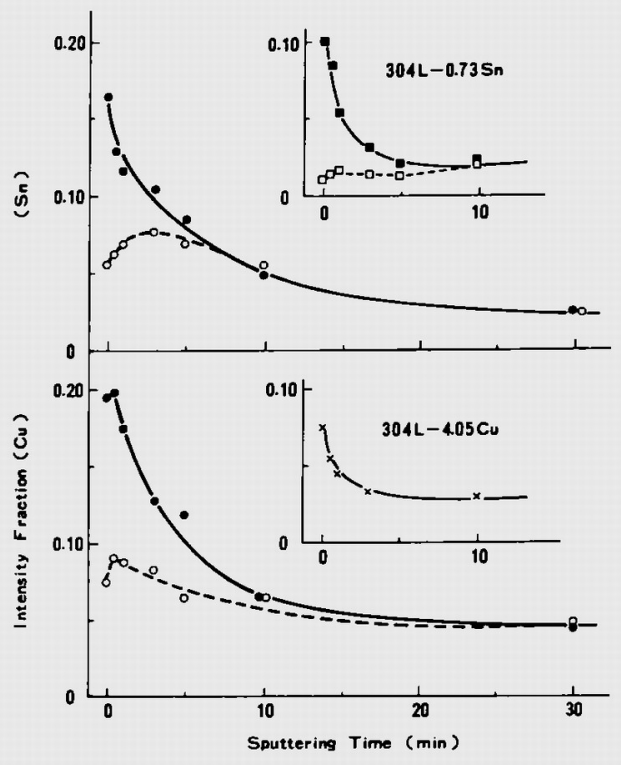

Fig. 7. Depth composition profile by AES of $304 \mathrm{~L}-3.92 \mathrm{Cu}-0.69 \mathrm{Sn}$.

が, $\mathrm{Cu}, \mathrm{Sn}$ を複合添加した場合は $\mathrm{Fe}-\mathrm{Cu}-\mathrm{Sn}$ 焼結

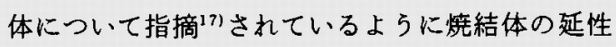
が20\%近く低下することがわかる。

Photo. 3 はこれら焼結材について $5 \%$ 塩水噴 壖試験を行い, $24 \mathrm{hr}$ 後での試料表面の発錆状況を 比較したものである。No.1の304 Lより303焼結体 （No.8）の方が点食が発生しやすくなっている が, Cu, Sn を複合添加した No.5およびNo.10の 試片の場合, 発錆は全く見受けられない。Fig. 8 お よび9にこれら試料表面のオージェ電子分光分析 の結果を示す。Fig. 8 より高 S 含有レベルの303焼 結体のほか, $304 \mathrm{~L}$ 系の焼結体においても表層に $\mathrm{S}$ が濃化していることがわかる。特にNo.5 の304 L -Cu·Sn 複合添加材の表層での元素の動きを詳細 に調べると,この $\mathrm{S}$ と同様 $\mathrm{Cu}, \mathrm{Sn}$ を表層へ向って 濃化(Fig. 9) し, Cu, Sn かi CrS 析出に伴 $5 \mathrm{Cr}$ 欠 乏層を補い, 発錆を㧕えているものと推定される。

\section{4. 結}

言

水噴霧 $304 \mathrm{~L}$ 粉末に被削性向上の目的で S (0.3 \%)を添加すると粉末性状が変化し，プレス特性 が低下するが，これに Cuを 4 \% 程度添加すると 王縮性が回復し，焼結密度も相応に高くできる。 
Table 3. Mechanical properties.

\begin{tabular}{c|c|c|c|l}
\hline No. & $\begin{array}{c}\text { Yield } \\
\text { strength } \\
\left(\mathrm{kgf} / \mathrm{mm}^{2}\right)\end{array}$ & $\begin{array}{c}\text { Tensile } \\
\text { strength } \\
\left(\mathbf{k g t} / \mathrm{mm}^{2}\right)\end{array}$ & $\begin{array}{c}\text { Elongation } \\
(\%)\end{array}$ & Note \\
\hline 1 & 12.4 & 24.4 & 14.8 & $304 \mathrm{~L}$ \\
\hline 5 & 16.4 & 25.4 & 11.0 & $\begin{array}{c}304 \mathrm{~L}- \\
3.92 \mathrm{Cu}-0.69 \mathrm{Sn}\end{array}$ \\
\hline 8 & 14.2 & 27.6 & 13.2 & 303 \\
\hline 10 & 17.2 & 26.6 & 10.8 & $\begin{array}{c}303- \\
3.82 \mathrm{Cu}-0.72 \mathrm{Sn}\end{array}$ \\
\hline
\end{tabular}

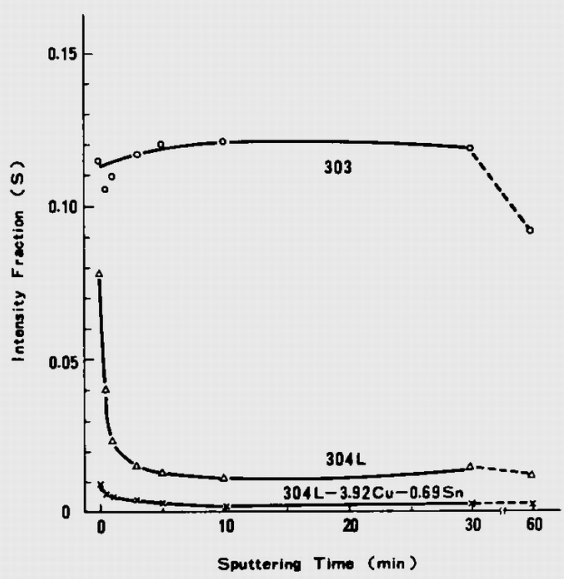

Fig. 8. Depth composition profile by AES.

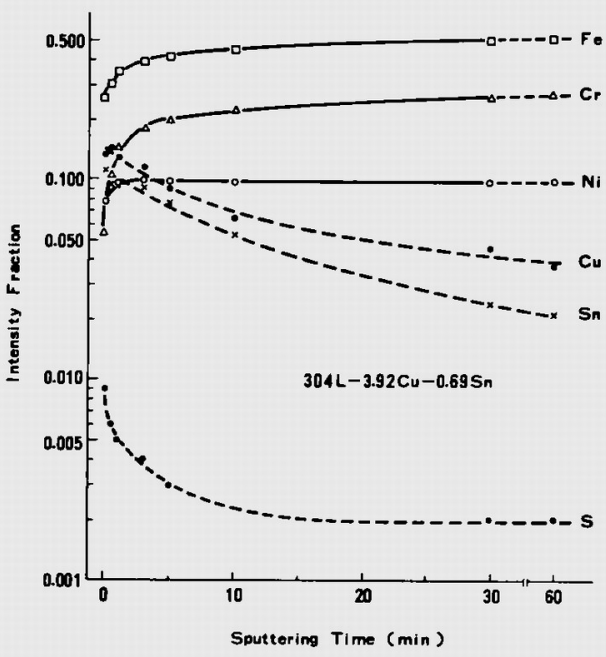

Fig. 9. Depth composition profille by AES.

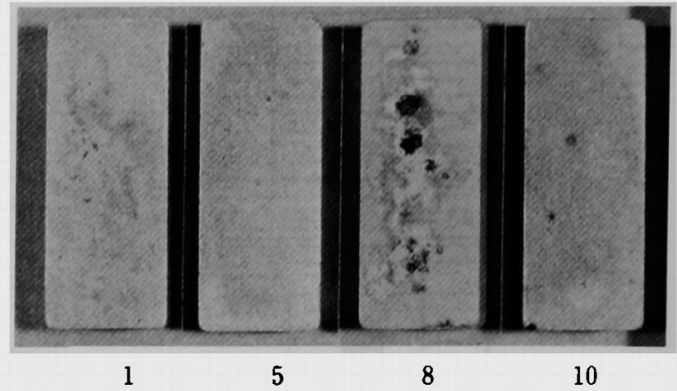

Photo. 3. Appearance of specimens after $5 \% \mathrm{NaCl}$ solution spray test $(24 \mathrm{hr})$.

$303 \mathrm{Cu}$ に Sn 複合添加するともとの S添加効 果に相乗された形で焼結体の切削抵抗が減少し, 工具寿命は

$$
304 \mathrm{~L}(\mathrm{Sn}) \rightarrow 303 \rightarrow 304 \mathrm{~L}-\mathrm{Cu} \cdot \mathrm{Sn} \rightarrow 303 \mathrm{Cu} \cdot \mathrm{Sn}
$$

の順に改善される。

$\mathrm{Cu} \cdot \mathrm{Sn}$ を複合添加すると焼結体の延性は $20 \%$ 近く低下するが，5\%塩水噴柔試験の結果ではS 添加に起因する焼結体の発錆を $\mathrm{Cu} \cdot \mathrm{Sn}$ の複合添 加により充分防止しらることがわかった。

ステンレス鋼に限らず, $\mathrm{Cu}$ や $\mathrm{Sn}$ を鋼中に数\% も添加すると熱間割れやミクロ偏析の原因となり 実用鋼種とはなりにくいが，一方，粉末成形・焼 結を主体とする粉末治金的な手法により製造可能 である。この事例のよ5に通常の溶製材に比べて 原料粉については合金設計の自由度ははるかに大 きく，新しい発想による粉末治金独自の鋼種開発 が期待される由縁である。

\section{（文献）}

1) M. Feir: SAE, Techn. Paper, No. 800308

2) 田中, 津和, 大森：精密機械，31(1964)，100

3 ) 田中, 三橋：精密機械，41（1975)，808

4) P.J. Anderssn and J.S. Hirschhorn : Mod. Develop. Powder Met., 10 (1977), 477

5) J.P. Muzik : Mod. Develop. Powder Met., 10 (1977), 403

6) F.B. Fletcher :Mod. Develop. Powder Met., 10 (1977), 453

7) P.W. Taubenblat W.E. Smith and F.A. Bladt: Mod. Develop. Powder Met., 10 (1977), 467 
8 ) O.W. Reen : Mod. Develop. Powder Met., 10 (1977), 431

9）加藤, 草加, 久田：鉄と鋼，66 (1980)，88

10）草加，久田，中村：電気製鋼，51(1980)，264

11）加藤，草加，久田：電気製鋼，51(1980)，252

12）達沢，深瀬，横田：防食技術，20(1971)，69

13）加藤，草加：粉体扰上び粉末治金，22(1975), 1
14) C.W. Kovach and A. Moskowitz: Trans. AIME., 245 (1969), 2157

15) J.S. Hirschhorn: Intradnction to Powder Metallurgy. APMI. N.Y, (1969), 81

16) S.K. Chatterijce and C.J. Thwaites: Metall., 24 (1970), 968

17) N.C. Kothari : Trans. ASM, 57 (1964), 909

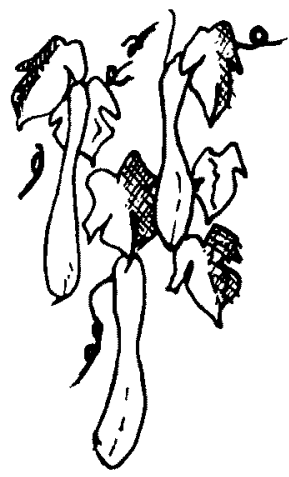

